This article was downloaded by: [Schleifer, Ron]

On: 25 March 2009

Access details: Access Details: [subscription number 909860250]

Publisher Routledge

Informa Ltd Registered in England and Wales Registered Number: 1072954 Registered office: Mortimer House, 37-41 Mortimer Street, London W1T 3JH, UK

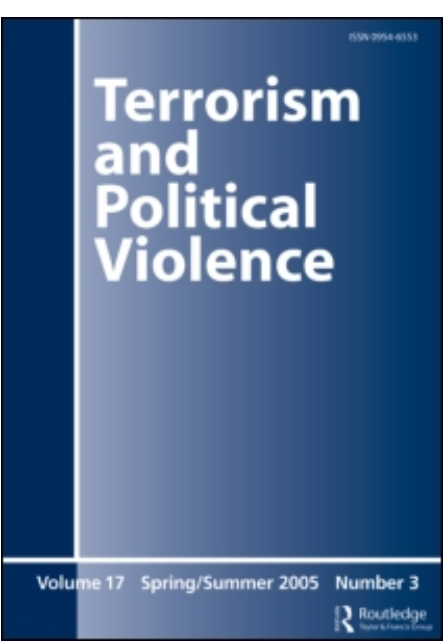

\title{
Terrorism and Political Violence
}

Publication details, including instructions for authors and subscription information:

http://www.informaworld.com/smpp/title content=t713636843

\section{Psyoping Hezbollah: The Israeli Psychological Warfare Campaign During the 2006 Lebanon War}

Ron Schleifer ${ }^{a}$

a Ariel University Center, Samaria

Online Publication Date: 01 April 2009

To cite this Article Schleifer, Ron(2009)'Psyoping Hezbollah: The Israeli Psychological Warfare Campaign During the 2006 Lebanon War',Terrorism and Political Violence,21:2,221 - 238

To link to this Article: DOI: $10.1080 / 09546550802544847$

URL: http://dx.doi.org/10.1080/09546550802544847

\section{PLEASE SCROLL DOWN FOR ARTICLE}

Full terms and conditions of use: http://www.informaworld.com/terms-and-conditions-of-access.pdf

This article may be used for research, teaching and private study purposes. Any substantial or systematic reproduction, re-distribution, re-selling, loan or sub-licensing, systematic supply or distribution in any form to anyone is expressly forbidden.

The publisher does not give any warranty express or implied or make any representation that the contents will be complete or accurate or up to date. The accuracy of any instructions, formulae and drug doses should be independently verified with primary sources. The publisher shall not be liable for any loss, actions, claims, proceedings, demand or costs or damages whatsoever or howsoever caused arising directly or indirectly in connection with or arising out of the use of this material. 


\title{
Psyoping Hezbollah: The Israeli Psychological Warfare Campaign During the 2006 Lebanon War
}

\author{
RON SCHLEIFER \\ Ariel University Center, Samaria
}

\begin{abstract}
The 2006 War between Israel and Hezbollah had a significant component of PSYOP. For the first time in its military history Israel deployed PSYOP as an inseparable part of its military operations. The performance of the PSYOP unit was less than satisfactory due to organizational factors and the general conduct of the war itself. This article analyzes the goals, the themes, and the delivery channels used throughout the PSYOP campaign. An attempt is made to answer the key question of whether this effort was effective.
\end{abstract}

Keywords 2006 Lebanon War, Hezbollah, Israel, PSYOP

\section{Introduction}

On July 12, 2006, a group of Hezbollah fighters crossed the border between Israel and Lebanon and ambushed an Israeli army patrol, killing four and kidnapping two of its soldiers. It was a brazen guerrilla operation, which marked the beginning of a new military confrontation between these two long-time enemies. In response to the attack, Israel unleashed a massive bombing campaign targeting the Hezbollah's strongholds and rocket caches in southern Lebanon and Beirut. Yet the Israeli offensive, a combined air and artillery operation, had little effect on the Hezbollah, which soon began bombarding northern Israel with Katyusha rockets. After several days, and with the Hezbollah's rockets reaching as far as south as Hadera, Israel launched a limited ground offensive in an unsuccessful attempt to clear southern Lebanon of the Hezbollah and bring the shelling to an end. However, it was only after a ceasefire, brokered by the United States and United Nations, came into operation that the rocket barrage and fighting finally stopped.

Ending on August 14, this thirty-three day long mini-war concluded with Israel's troops withdrawing from southern Lebanon, replaced by a mixture of Lebanese and multinational forces. The war ended with neither side able to claim clear victory, each having been dealt several substantial blows. Lebanon saw a part of its capital, Beirut, devastated and its southern territories pounded. The Hezbollah itself was left with its military infrastructure in tatters. And Israel, one of the region's leading military powers, suffered the abject humiliation of being unable to defeat a minuscule fighting force numbering a mere 600 to 800 fighters. ${ }^{1}$ Not surprisingly, the Hezbollah could, and did, congratulate itself on its ability to withstand the Israeli onslaught.

Dr. Ron Schleifer is a senior lecturer at Ariel University Center in Samaria.

Address correspondence to Ron Schleifer, 4 Frankfurter St., Jerusalem, Israel 97225. E-mail: conschle@netvision.net.il 
The events of July and August 2006 were yet one more bloody chapter in the history of the long and violent conflict between the Hezbollah and Israel, which began in the mid-1980s. It was then-with Israel firmly lodged in southern Lebanon-that the Hezbollah (Party of God) succeeded in outmaneuvering the largely secular AMAL, replacing it as Lebanon's principal Shi'ite organization. Its aims included improving the Shi'ites' general political and economic status in Lebanon, establishing an Iranian-style Islamic republic and, most urgently, ejecting the Israeli forces from the area. To this end, it embarked upon a long-term campaign combining guerrilla with psychological warfare. Fifteen years later it had achieved its goal, persuading Israel that it had little to gain and all to lose by remaining in the country. In May 2000 the last Israeli forces withdrew from southern Lebanon, which raises the intriguing question of how was this goal achieved?

The following article will trace the course of Israel's 2006 psyop campaign, which targeted various groups within the Lebanese camp: Hassan Nasrallah, the head of Hezbollah; the Hezbollah itself; the Lebanese Shi'ite community, the bulwark of the organization's support; and, finally, Lebanon's Sunni, Christian, and Druze populations, who, it was hoped, would prove to be less than happy with the chaos the Hezbollah had brought upon their country. Admittedly, a complete picture of Israel's psyop offensive should include the messages directed at both neutral and domestic audiences. However, this article seeks specifically to analyze and assess the evolution of Israel's psyop campaign against the Hezbollah.

According to its operational principles, psychological warfare seeks to promote specific military and political goals during wartime. It does so by targeting three key audiences - domestic, enemy, and neutral-exposing them to a variety of crafted messages. This, in the hope of persuading them to act, support, oppose, or remain indifferent to a particular course of action or policy all in support of victory.

The successes and failures of Israel's psyop offensive have significant regional and global implications. A protégé of Iran, many of Hezbollah's fighters are either graduates of Iranian-based training camps or were drilled in guerrilla warfare by Iranian instructors posted to Lebanon; while the religious and ideological make-up of Lebanon's Shi'ite community, from which the Hezbollah draws most of its support, is similar to that of Iran's majority Shi'ite population. Taken together this means that any lessons drawn from the Israeli psyop campaign could prove invaluable in assessing the role psyop should play in any future clash with radical Islam, and, as seems possible, Iran.

\section{Methodology and Data}

The Israeli psyop campaign will be analyzed using Lasswell's classic model of communication, Who says What to Whom, in Which Channel and to What Effect, looking at the sender (psyop initiator), target audiences (enemy), content (themes and messages used), channels of delivery and, finally, effect assessment. This model also forms the basis of the U.S. Army's psyop campaigns, as outlined in the U.S. Army PSYOP Field Manuals. ${ }^{2}$ Accordingly, the content and effectiveness of the Israeli psyop messages will be considered in the context of: (a) their selected (enemy) target audiences; (b) the goals, covert and overt, they were designed to achieve; (c) the operational principles-i.e., psychological techniques-used to realize these goals; and (d) the technical means used to convey said messages. It will conclude with 
an assessment of whether, and to what degree, the Israeli campaign influenced its chosen target audiences, attained its goals, and advanced the cause of victory.

The IDF body in charge of conducting psyop (Lasswell's "Who") is called the MALAT (Mercaz L'Mitzaei Toda'a: The Center for Consciousness/Perception Operations). Currently part of the Army GHQ Operations Department, the MALAT was established in 2005, Israel's previous pysop unit having been practically disbanded some six years earlier by the head of military intelligence. Forced to start virtually from scratch, the MALAT drafted into its ranks both intelligence officers and psychologists who began exploring the possibilities inherent in the use of psyop in wartime. ${ }^{3}$

The messages during the 2006 campaign (Lasswell's "Channel") were distributed using "old" (leaflets) as well as "new" (SMS, websites) methods. Of these, it was the new modes of communication, and especially the Internet, which proved valuable when assessing the enemy's response to Israel's psyop offensive. In previous conflicts, any assessment of the enemy's reaction was based either on speculation, enemy's media, captured documents, or on the interrogation of POWs. Currently, Lebanese media and blogs proved extremely helpful in estimating the Israeli psyop messages' impact on their Lebanese audiences. Interviews conducted with IDF soldiers and Hezbollah statements, broadcast on the organization's various television and radio networks, were another important source of material; though in the latter case, assuming that these were a part of the Hezbollah's psyop offensive, they should, and were, taken with a large grain of salt.

\section{The Reasoning Behind the Israeli Campaign}

The Israeli 2006 psyop campaign was predicated on the assumption that psyop could assist the army in defeating the Hezbollah. It signalled a remarkable transformation in Israeli military thinking with regards to psychological warfare. The transformation began in the late 1990s, when the then head chief of staff General Shaul Mofaz began to put increasing emphasis on targeting the enemy's mind and persuading it to accept a designated point of view; an approach continued by his successors Moshe Ya'alon and Dan Chalutz. It was Ya'alon who, during the Second Intifada (20002005), coined the phrase "to burn into the [enemy's] consciousness," a phrase that has since become an integral part of IDF argot.

But this was not the only new development in Israeli military thinking. Dan Chalutz, the Israeli head chief of staff during the Lebanon war, was a firm believer in EBO (Effect Based Operations). ${ }^{4}$ A U.S. Air Force doctrine brought to Israel by disciples of the defense strategist Andrew Marshall, EBO rejects the notion of a full clash with the enemy, opting instead to target, largely through precision bombing, a number of key objectives; this, on the assumption that destroying these would cause a chain reaction resulting in the enemy's collapse. The impetus behind the new doctrine was technological innovations such as smart bombs, stealth bombers, and information warfare. It was accompanied by new concepts of warfare such as "molecular warfare," "swarming," "consciousness," and "soft tissue," which became fashionable in IDF and some academic circles. ${ }^{5}$ All tended to distance senior commanders from the more traditional military goals of pursuit, victory, and elimination. ${ }^{6}$

In theory psychological warfare and EBO are ideal companions. Both seek to influence the minds of a designated audience. Psyop does that through delivery of information and EBO through a series of violent targeted strikes. However, Chalutz 
and his staff had little idea how to make the two work together effectively. ${ }^{7}$ Moreover, they seemed to have been victims of a common, yet pivotal, conceptual misunderstanding: ignoring the fact that while EBO strategy is essentially a "war psychologically waged," psychological warfare is mostly a non-violent affair. ${ }^{8}$ This confusion between the two doctrines was one of a few misconceptions of the high command.

The coordination problem was derived from a deeper conceptual problem regarding EBO. The doctrine was imported from the U.S. Air Force. There is indeed an abundant literature on air power and its effect on war since Douhet's to date ${ }^{9}$ but EBO was based mainly on the First Gulf War and the Kosovo campaign, which did not provide enough experience to draw upon for the case of Lebanon. ${ }^{10}$ Chalutz's mistake, it seems in hindsight, was to confuse "effects" with "impact." The former is about the psychological consequences of some military measures (such as bombing London's St. Paul Cathedral by the Luftwaffe to lower British morale), and the latter is about air superiority and the assistance to ground forces where the enemy knows he is never safe. This "impact" is a direct result of conventional warfare. Both "effects" and "impact" are part and parcel of a "war psychologically waged" which left nonviolent psyop to stand alone and struggle for recognition throughout the war.

The EBO doctrine was not the only problem to beset the IDF in 2006. As head chief of staff, Chalutz introduced a new department into GHQ known as Itsuv HaMa'aracha (Battle Design). This led to a degree of operational and organizational confusion, as did faulty communications with the Army Spokesman Unit. And, it was in this rather nebulous and confusing climate that the newly resurrected psyop unit, the MALAT, began to operate.

Israel's psyop problems were compounded by the fact that militarily, politically, and psychologically the war could not have come at a worse time. Militarily, Israel was exhausted, having spent the past five years in bloody conflict with the Palestinians, trying to put down the Second Intifada, a conflict that began only a few months after Israel's pullout from Lebanon in 2000. Moreover, having focused for much of its time on the ins and outs of urban guerrilla warfare, the IDF lost much of its fighting know-how as regards to combat on the very different terrain of Lebanon. ${ }^{11}$ Psychologically, Israel was still reeling from its highly contentious disengagement from Gaza; politically, the prime minister, a lawyer by training, and the defense minister, a labor union activist, had little military experience. In addition, there was a personal lack of communication between the prime minister, defense minister, and foreign minister. ${ }^{12}$ Given this state of affairs, Chalutz had little difficulty in convincing the government of the merits of his EBO-based strategy, which, he promised, would guarantee a short, effective, surgical operation.

Nor were these all of the prospective psyop campaign's difficulties. Following its withdrawal from southern Lebanon, Israel lost most of its HUMINT assets in the country, and was forced to rely largely on technically based intelligence. This suited the Hezbollah, which carried out most of its activities at night or in dense scrub. It engaged in an impressive, and ultimately successful, deception campaign, giving the impression that its meager supply of rockets was rusting away on obsolete launch pads. Yet at that time it was busy constructing gigantic subterranean military complexes capable of launching a prolonged missile attack against Israel. ${ }^{13}$ To further disguise its true potential, Hezbollah activists conducted a continuous shouting and cursing campaign against Israeli soldiers across the border, giving the impression that the organization's abilities were limited to no more than futile posturing. 
Nevertheless, valuable information was gathered by AMAN and the air force intelligence arm on probable digging locations throughout the south, but it was kept under the highest level of secrecy so even high ranking field intelligence officers were kept out of the information loop. ${ }^{14}$

As the Northern Command was put on high alert after the abduction of the two soldiers on July 12, the MALAT was alerted as well. It had the full backing of the army's high command. ${ }^{15}$ A significant part of the EBO plan called for the strategy of decapitation: the elimination of the commander in the field and his communications means by air and without the involvement of ground forces. ${ }^{16}$ It was this strategy which, arguably, led Israel's psyop operation to focus its attention on the Hezbollah and especially its leader Hassan Nasrallah. But the Israeli psyop offensive went beyond targeting the Hezbollah; it also targeted its supporters and opponents, as well as the average, uncommitted Lebanese in the street.

\section{The Campaign's Objectives}

Israel has yet to reveal the specific objectives of its 2006 psyop campaign. Nevertheless, a review of events on the ground together with a close analysis of the psyop messages targeting Lebanon suggest that Israel's aims were twofold. First, there was the purely military goal of bringing an end to the shelling of northern Israel. Second, there was the more politically orientated goal of destabilizing and undermining the Hezbollah's position in Lebanon. This second, political goal was, in turn, divided into several more specific objectives. These included: compromising Nasrallah's position within the Hezbollah; alienating the Hezbollah from Lebanon's wider Shi'ite community; and deepening the divide between the Hezbollah, its Shi'ite supporters and external sponsors, on the one hand, and the country's non-Shi'ite population, on the other-all goals which could, individually and collectively, help cripple the Hezbollah. It should be pointed out that the two overarching Israeli objectives were interconnected, in that weakening Nasrallah and his organization might bring the rocket attacks to an end, while putting a stop to the latter would constitute another nail in the Hezbollah's and its leader's coffin. This was probably the overriding reason why most of the Israeli psyop messages gave Nasrallah pride of place. Another reason was the long-time Israeli habit of personalizing its conflicts. Thus, Arafat encapsulated the Palestinian problem, while Assad embodied its conflict with Syria. In the case of the Hezbollah it seemed therefore only natural to equate the figure of Nasrallah with the organization itself. ${ }^{17}$ However, the decision to focus the campaign around Nasrallah was arrived at only after much internal wrangling.

Targeting an enemy leader is a delicate matter. There are two opposing attitudes as to whether or not a concerted attack against the enemy's leadership is an effective strategy. Communities under siege might unite behind their leaders. Accordingly, leaders who in more peaceful periods are subjected to intense critical scrutiny might in times of crisis be forgiven, and attempts to target the enemy's leadership might be futile. Worse, it may even backfire, encouraging the enemy population to rally round its leaders. On the other hand, a psyop offensive underlining what some may already suspect but dare not admit as regards their leaders, would have the desired effect of causing the enemy's morale to plummet.

Israel took the chance and decided to launch a full-scale psyop offensive against Hezbollah's head, Sheikh Hassan Nasrallah. However, the decision to target Nasrallah himself presented Israel with a whole new problem: what form should the attack 
on Nasrallah take? Should Israel simply list dispassionately the Hezbollah leader's errors and crimes, letting the Lebanese draw their own conclusions? Or should it launch a colorful and emotive attack on Nasrallah's honor? This latter option was particularly appealing, as turning Nasrallah into a political and military joke might cause his cohorts to lose their cool and thus have an adverse effect on their battlefield performance, which in turn could be offered up as further proof of the Sheikh's dangerous ineptitude. It might also help persuade his less hard-core supportersnot to mention the Lebanese at large - to cast aside this obvious liability. Yet it was a risky strategy since idolization of Nasrallah within the Hezbollah and Shi'ite community was so high that savaging their revered leader's honor might boomerang, with his supporters rallying even further round Nasrallah. ${ }^{18}$

MALAT decided to make fun of Nasrallah. Humor can cross physical and cultural borders and rational, critical thinking. This, together with an awareness of the importance attached by Arab culture to matters of honor, were key to the decision to strike at the Hezbollah's leader's dignity. ${ }^{19}$ The decision was supported by the fact that on June 1, 2006, a few weeks before the outbreak of fighting, Nasrallah's supporters demonstrated in Beirut about the way in which the Lebanese satirical television program Bas-Met-Watan lampooned their revered leader-a disproportionate reaction to a light-hearted political satire. ${ }^{20}$ It also signified for the MALAT the high organizational skill of Hezbollah, as the demonstrations could have been organized from above and may not necessarily have reflected a popular sentiment. The MALAT was also aiming to drive a wedge first between the general population of South Lebanon and Hezbollah and somewhat later, the population of the entire country. The personal attack against Nasrallah was put on hold because the MALAT targeted the Lebanese government instead. It was only when this approach failed to elicit any significant response that Nasrallah became the focal point of Israel's psyop campaign. ${ }^{21}$

Targeting Nasrallah had one more advantage: it allowed Israel to personalize its psyop campaign by representing the Hezbollah and Nasrallah as being one and the same. This made it easier for the MALAT to formulate its psyop messages, as it is always simpler to target individuals than faceless organizations. Moreover, by singling out Nasrallah as the personification of the Hezbollah, Israel could impress upon the Lebanese population both the fact that it had no quarrel with them and that it was Nasrallah — read Hezbollah — who was responsible for the hardships they were living through.

\section{The Israeli Psyop Campaign in the Context of the War}

On July 12, 2006, following the abduction of its two soldiers Ehud Goldwasser and Eldad Regev, Israel launched a massive air and rocket offensive against Lebanon, followed by a limited ground offensive several days later. Israel launched a full-scale ground offensive only during the last three days of fighting, hoping to improve its post-war negotiating position. This hesitancy to deploy large-scale forces was mirrored by Israel's reluctance to call the thirty-three-day campaign a war: the Knesset announcing, on July 18, the existence of a "special situation" instead.

The psyop offensive against Nasrallah, launched a week after the outbreak of war, was conducted on a scale unheard of in the annals of Israeli psyop history. At first, Israel's psyop messages - what with the newly formed MALAT having found itself thrown headlong into battle and with little to guide it in terms of 
precedence - were of a fairly general nature. Drawing upon themes and imagery used in conflicts all over the globe, i.e., picturing enemy leaders as puppets manipulated by external forces, the MALAT depicted Nasrallah as a genie emerging from an Iranian or Syrian Aladdin's lamp. ${ }^{22}$ The next stage was a more targeted-operational affair designed to avoid both a humanitarian disaster in the south as well as to deflect criticism of Israel's bombing campaign. It also sought to force the Lebanese government into confronting the Hezbollah, owing to the pressure placed on it by the huge numbers of refugees streaming northwards.

Once Israel's ground forces entered the fray, the psyop campaign took a new turn, in part owing to the fact that the Hezbollah was quick to deploy counter-psyop measures by quoting Israeli casualty reports to boost Lebanese morale. The MALAT, in close cooperation with AMAN, responded immediately, listing the hundreds of Hezbollah operatives killed in combat. The idea was to undermine both Hezbollah morale as well as Nasrallah's credibility. As the war drew to a close, Israeli ground forces were ordered to gather visual material to be used in the subsequent diplomatic war between the two sides. This tactic failed largely owing to Israel's unimpressive showing in the field. Few if any of the IDF operations in the last three days of combat could be hailed a success, thus rendering any psyop value to be gained from them null. True, the daring raid by Israel's special forces on Ba'albek, far behind enemy lines, was captured on film and broadcast, but given the by then gloomy climate in Israel, it had little effect. ${ }^{23}$

\section{The Operational Principles: Messages and Techniques}

\section{Targeting the Enemy's Key Levers}

In any psyop battle it is essential to identify the enemy's key motivational levers, so as to target and neutralize his will to continue hostilities. ${ }^{24}$ Doing so demands a close analysis of the enemy's messages in order to determine his specific psyop objectives and to assess whether, and to what degree, these have been achieved. ${ }^{25}$ Having pinpointed the enemy's messages, immediate tactical psyop action must be taken to minimize the harm done, render the messages ineffective and, if possible, stop them from being used altogether. This activity should be accompanied by more long-term strategic action designed to further one's own military and political objectives.

The Hezbollah has long recognized psyop's importance, launching newspapers, magazines, and radio and television networks, all fuelled by a large research unit charged with gathering, collating, and assessing conventional, political, and cultural intelligence. Staffed by Hebrew speakers, the unit monitors the Israeli media, preparing material to be broadcast on television and/or posted on various moqawama (resistance) websites. ${ }^{26}$ The most famous of the organization's media channels is Al Manar (the Beacon) television station. For Israeli audiences, the station provides footage hot off the battlefield, news programs, drama series, and video clips. ${ }^{27}$ Initially, prior to Israel's withdrawal from Lebanon, Al Manar could be seen only by Israeli solders based in Lebanon. In time, however, the station spread its broadcast as far south as Haifa and, subsequently, throughout Israel where it became especially popular among the country's Arab citizens. ${ }^{28}$ To combat this threat, the Israeli Air Force tried to destroy Al Manar's broadcasting capabilities. These efforts failed because Hezbollah had prepared relay stations in advance to ensure the continuation of their broadcasts. 
The message of Hezbollah was to portray Israel as a weak and sickly state, populated by a decadent lot, evoking the image of a tattered cobweb about to be blown away. These messages, aimed at the organization's domestic audience, sought to encourage it to continue its battle against Israel in the face of what appeared to be impossible odds. Given Israel's fragile state, it was a battle bound, in the long-run, to be crowned with success.

In order to counter this negative representation, Israel showered Lebanon with leaflets showing Nasrallah imprisoned behind a web of steel bars. The caption read: "He (Nasrallah) assured you that Israel is a spider's web ... but encountered a web of steel instead." 29 This caricature was one of several psyop messages designed to convince the Lebanese population at large, and somewhat also the Shi'ite supporters of Hezbollah, that Israel was still a power to be reckoned with. However, this powerful image was severely damaged when thousands of Israelis fled their homes in northern Israel following the Hezbollah rocket attacks.

Another longstanding Hezbollah psyop message sought to convince its home front - especially its non-Shi'ite component - that in doing battle with Israel, the organization was motivated not by narrow sectarian or religious considerations, but by the good of Lebanon. ${ }^{30}$ In a bid to undermine this claim, Israel published a second caricature depicting Nasrallah cowering behind the Lebanese people. By highlighting the Hezbollah's tactic of using civilians as human shields, the MALAT maintained that civilians' welfare was the last thing on Nasrallah's mind, and it was they who were paying the price for his aggressive sectarian policies.

Nasrallah had from the very start labored to promote himself as a regional leader and religious authority. ${ }^{31}$ It was in this dual capacity, Nasrallah insisted, that he was charged with the holy task of destroying Israel. Hoping to cut Nasrallah's regional and religious pretensions down to size, Israel declined to call the Hezbollah's leader by his surname, referring to him dismissively throughout the conflict as Hassan: a commonplace Arabic name of no distinction. Denying Nasrallah the dignity of a surname and addressing him by his given name had the added advantage of toppling him from the elevated heights of a religious leader to that of a mere nobody.

\section{Driving a Wedge}

Based on the age-old principle of divide and rule, driving a wedge targets enemy's social cohesion by inflaming communal tensions, widening preexisting divisions, and creating new ones. This can be achieved in several ways: by creating friction between the political and military sectors, or by targeting the army itself and stirring up resentment within the ranks. Class animosity can be an effective tool by drawing attention to how the poor are fighting and dying on the front, while the rich are living it up back home. ${ }^{32}$ Religious and ethnic minorities, too, are natural targets for socially divisive messages, and given Lebanon's long history of communal strife it is hardly surprising that Israel made keen use of the divide and rule principle in this context too. Targeting Lebanon's Druze, Christian, and Sunni populations, the MALAT contrived to further alienate these communities from the Hezbollah and its Shi'ite supporters.

Israel sought to persuade the latter that the organization was a foreign agent busy pursuing an agenda that had little to do with Lebanon's true interests. To this end, the MALAT, in addition to bombarding Lebanon with various standard paper 
leaflets, all banging away at this theme, showered Beirut with thousands of car air-fresheners in the shape of a cedar tree-Lebanon's national symbol-with Nasrallah's head cowering from behind the tree. It had several layers of meaning. Nasrallah was once again hiding behind and endangering Lebanon's population. ${ }^{33}$ On the bottom of the air-freshener was printed a pun, "Let's part with a good smell," which also means in Arabic "evaporate." Finally, if there was anyone left who somehow still failed to get the message, the air freshener was accompanied by a leaflet pointing out that: "It is up to you to allow the fresh clean scent of cedars to once again fill Lebanon."

According to the Lebanese blog "Beirut Live," in marked contrast to the fate of the bog-standard psyop leaflets, which were gathered and burned almost immediately, the Lebanese swooped on the Israeli air-fresheners. ${ }^{34}$ For a few months, thousands of Lebanese would have a conscious and subconscious reminder of who was using them as bait.

In order to deepen the divide between the Hezbollah and the Lebanese at large, the MALAT reminded the Lebanese via printed leaflets how the organization, by setting up command posts, rocket-launching pads, and generally hiding in their midst, had turned them into legitimate military targets. Expelling the Hezbollah from your homes would, these leaflets promised, ensure your safety, saving you from further Israeli bombardment. Israel sought to isolate and alienate the organization from Lebanese society by promising that once rid of the Hezbollah, the Lebanese would be safe from attack. This message was also a riff on the classic psyop theme, "We do not have a quarrel with you, only with your evil leadership."

On the assumption that most Lebanese had had enough of outside, i.e., Syrian and Iranian, interference, the Israeli psyop offensive stressed the fact that Nasrallah and Hezbollah received their orders directly from Damascus and Tehran. The massive anti-Syrian demonstrations following the murder, allegedly at Syria's instigation, of Rafik Hariri, Lebanon's Sunni prime minister, suggested that such a message would fall on receptive ears. Hoping to capitalize on this anti-Iranian, antiSyrian mood, MALAT produced several leaflets highlighting the two's overt and covert links with Presidents Assad and Ahmedenajad. In addition, Israel distributed a caricature in which Nasrallah, in the form of a cobra, was seen dancing to the tune of a flute wielded by Khaled Mashaal, the Damascus-based Hamas leader. Depicting Nasrallah as a snake was also a way of attacking Nasrallah personally and portraying him as a poisonous, death-dealing fiend. In a similar vein-one that mixed cultural symbols and psyop - the MALAT also distributed a cartoon showing Nasrallah playing in the sand: a reference to a poem by the renowned Syrian poet Nizar Qabbani, which speaks of dreams, which, like sand castles, crumble into dust. $^{35}$

All this promising activity was, however, undermined by the unfortunate damage caused to noncombatants. Bombing Beirut and southern Lebanon in order to put pressure on the Lebanese government, led, no matter how surgically applied, to civilian casualties. Subjecting Beirut's Dakhia quarter, a Shi'ite stronghold and the location of Hezbollah's headquarters, to a bombing campaign caused buildings throughout Beirut to shake; none of this endeared Israel to Beirut's population. The dropped leaflets advising the civilian population to flee the area helped at those moments to focus anger at Israel rather than gratefulness for its effort. The Hezbollah was quick to point out to the Lebanese civilians that they both were victims of 
a bloodthirsty enemy for whom all Arabs were the same. Flying its own flag alongside the Lebanese flag amidst the ruins of Beirut, it signalled its undivided commitment and loyalty to the country.

In addition to alienating the Hezbollah from Lebanese society, Israel also did its best to stir up trouble within the organization. The campaign pointed out how while the Hezbollah's foot soldiers were spilling their blood on the front, their commanding officers were safely tucked away in the rear. Nasrallah's sole contact with the front, the MALAT noted, was by video cassettes. So where exactly was this so-called great hero, who sent you to die and then safely secreted himself outside the line of fire? Such contemptuous comments would, it was hoped, not only provoke feelings of resentment among the Hezbollah's fighting forces, but also, given most Arabs' acute sensitivity to matters of honour, goad Nasrallah out of hiding, thus exposing himself to a direct Israel attack.

\section{Undermining Credibility}

Maintaining credibility had always been a crucial part of the Hezbollah's psyop campaign against Israel. However, in 2006, the Hezbollah, in an uncharacteristic lapse of judgment, began to embellish its reports with exaggerated claims. The MALAT was quick to seize the opportunity to undermine Nasrallah by exposing him as a liar, and as a result, to cast doubt on the trustworthiness of his actions and policies as a whole.

Accordingly, when Nasrallah boasted that the Hezbollah had, in the course of the fighting, suffered virtually no causalities, the MALAT immediately published a long list of the organization's combatants killed in action. When, in response, the Hezbollah alleged the list to be a complete fabrication, it produced a second, detailed record of the Hezbollah dead. ${ }^{36}$ Later, having hijacked Al Manar's broadcasting frequencies, Israel beamed pictures of the Hezbollah dead over the air, thus backing its claim with incontrovertible visual proof. Broadcasting these images using the organization's own television station had the added advantage of underlining Israel's technological skills and further lowering the organization and its supporters' morale.

Similarly, when Nasrallah sought to justify the kidnapping of the two Israeli solders - the event that triggered the conflict - by claiming that such action had been necessary to secure the release of Samir Kuntar, who was serving a life sentence in Israel for terrorist activities, ${ }^{37}$ the MALAT seized the opportunity to expose Nasrallah, if not as a liar, then as a man of little or no political judgment. To this end, it drew attention to an interview with Walid Jumbalat, in which the Druze leader noted that had the Hezbollah passed on to Israel information about Ron Arad, the Israeli pilot missing since 1986, Israel would have released Kuntar. The implication being that the kidnapping had been a reckless act for which Lebanon was now

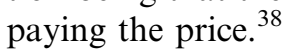

Detailing Nasrallah's failures to foresee the ferocity of the Israeli response was intended to undermine his standing as a credible leader. In stark contrast to his habit of presenting himself as infallible, Israel sought to expose him as a mere mortal. Similarly, Nasrallah's godlike conceit, resulting in countless mistakes and miscalculations, had proved an unmitigated disaster for Lebanon and its people. ${ }^{39}$ The cumulative subtext of the Israeli psyop campaign suggested that, in sum, Nasrallah's policy was a mix of flawed and misguided thinking fused with numerous lies designed to promote some (not so) hidden agenda. ${ }^{40}$ 


\section{Modes of Communication}

In order to reach its Lebanese targets, Israel exploited a variety of communication techniques, some well-worn, others relatively new. According to one estimate, in the course of the thirty-three-day campaign Israel penned several dozen leaflets and, printing hundreds of thousands of copies of each, dropped them from the air onto Lebanese territory. ${ }^{41}$ The problem-one common to all enemy-targeted psyop messages - was how to persuade the Shi'ite community and Hezbollah to take note of leaflets showered at them from the sky by airplanes that normally drop bombs on their homes. The solution was to use caricatures, which tend both to draw the viewers' eye and succinctly summarize the psyop message.

Radio was another means used to reach the Lebanese population, with Israel taking advantage of Radio South, a radio station it had set up in the late 1970s. Rechristened, in 2001, the Voice of the East, the station served mainly the population of southern Lebanon, offering an attractive mix of music and entertainment leavened with information, tips, and op-ed pieces. ${ }^{42}$ However, Israel realized that, particularly in wartime, this was not enough to stop listeners from switching off in disgust what was, essentially, an enemy station. In order to prevent this, it began to broadcast details of likely assault zones, advising local residents to leave the targeted areas before the Israeli bombers or ground forces arrived; this in the expectation that, anxious for their lives, the Lebanese would stay glued to the radio and so exposed to the station's psyop messages. But if this tactic allowed the MALAT to multiply the number of listeners to the Voice of the East, it also, inevitably, revealed Israel's operational plans to the Hezbollah, so that, forewarned and forearmed, it was able to ambush Israeli ground troops or, alternatively, flee the area.

Israel also made use of some relatively new communication technologies, including mobile telephones, satellite technology, and the Internet. It relayed over the phone prerecorded messages, similar to those used in telemarketing campaigns; despite the likelihood of people, as with telemarketing messages, slamming down the phone in irritation. More effectively, Israel texted (unidentified) SMS messages to Lebanese mobile phones to the tune of: "Do you feel the Hezbollah is to blame for current violence? Make your voice heard! Reply ..." ${ }^{43}$ It also launched a website under the name: "All 4 Lebanon." Set up anonymously, the website, in the colors of the Lebanese flag and the cedar tree, was like the aforementioned SMS messages, a prime example of grey psyop in which the source of the message is unclear; although in this case one could make an educated guess. The site called upon those for whom Lebanon's interests were dear to heart to report the location of the Hezbollah's rocket launchers and fighting units. Any potential ditherers were assured that their information would in the short-run safeguard them and their neighborhood from attack, and in the long-run, help secure Lebanese independence. Quite how many Lebanese contacted the site is unknown; however, given that within days Hezbollah hackers were targeting the website in an effort to neutralize it, it seems that enough had called to seriously unnerve the organization.

\section{An Assessment of the Israeli Psyop Campaign}

The key question asked at the end of every psyop campaign is whether and to what degree, did the offensive realize its objectives? Did the investment in time, money, and manpower pay off? Did the campaign achieve its goals and promote the cause 
of victory? Or was it a wasted effort, which had little effect on the perceptions and behavior of its target audience?

Psyop's primary goal is persuasion, which in turn is partially predicated on reaching the prospective target audience. Yet, conveying information is not the same as convincing an audience to adopt a particular point of view and action. Confusing the two is a common and oft-made mistake, partly because, while the process of persuasion is a slow one, that of communicating, especially in today's information age, is instantaneous. Hence, any evaluation of Israel's psyop campaign must distinguish between these two aspects of psyop - the tactical (information) and the strategic (persuasion) - and assess each separately, in its own right.

Given the short time period that has elapsed since the end of the fighting, any conclusive appraisal of the 2006 conflict is as yet impossible. However, enough is known about the course of the conflict and, no less importantly, its aftermath, to claim that on the level of persuasion, Israel largely failed to achieve its immediate psyop goals. Katyusha rockets continued to rain down on northern Israel until the very end of the war. Nor were there, apparently, any rebellions, internal settling of accounts, or even significant signs of unrest within the ranks of the Hezbollah. On the contrary, the war ended with Nasrallah firmly still in control, although with his military deputy deposed. Israel also drew a blank in its attempts to undermine the Hezbollah's Iranian and Syrian sponsors. Worse, the two, by investing heavily in the reconstruction of Lebanon's devastated towns and countryside, only tightened their grip on the country.

Based on an overview of Lebanese bloggers (admittedly in the English language) and statements of non-Shi'ite Lebanese politicians, the Israeli psyop campaign was not a total loss. It did manage to underline the existing fissures between the Hezbollah and its supporters, on the one hand, and the Christian, Druze, and Sunni communities, on the other. ${ }^{44}$ True, the Lebanese did not flood the streets in their thousands to protest against the havoc the Hezbollah had wrought on their country. Nor did they take any concrete action against the organization in an effort to bring the war to an end; but perhaps this was too much to expect in the context of current Lebanese politics. As for driving a wedge within the Shi'ite community, between those supporting AMAL and those supporting the Hezbollah, there is no evidence that Israel even tried to do so. ${ }^{45}$

On the other hand, mutterings of discontent among the population at large were rife, while leading Lebanese politicians, including Druze leader Walid Jumbalat and Dory Chamoun, the head of the Christian Liberal National Party, engaged in the kind of vitriolic attacks on the Hezbollah leader unheard of in recent Lebanese history. ${ }^{46}$ Admittedly tension between the Shi'ite Hezbollah and the remainder of Lebanon had long been bubbling under the surface, and the physical damage was a good enough reason to express bitterness. Yet arguably the Israeli psyop campaign, by taking the first steps by means of a ridicule campaign, had a significant role to play in cracking the image of infallibility, sanctity, and ruthlessness Nasrallah was cultivating, which finally culminated in bringing to light and exposing - even deepening - the existing divide between the communities. ${ }^{47}$ Presenting Nasrallah as an inveterate liar and figure of fun had, it seems, created the desired atmosphere. It served to fracture the seemingly impenetrable psychological barrier that the Hezbollah had erected around its chief. Thus, with a few caricatures and some carefully formulated, timely broadcasts, the Israeli campaign helped aggravate preexisting feelings of resentment and animosity within Lebanese society. 
On the tactical level - that of informing - the Israeli psyop campaign did reasonably well. The combination of leaflets and radio messages convinced a large number of civilians to evacuate prospective danger zones, which in turn allowed the army to operate relatively freely and with a minimum of civilian casualties. On the other hand, the effort to achieve Iwo Jima type photographs during the last three days of the war failed miserably. The plan was to capture Bint Jbeil, a Hezbollah stronghold well beyond enemy lines, and take pictures of the Israeli flag flying over the town. This image was meant to encapsulate Hezbollah's defeat and Israel's victory. However, despite having overrun Bint Jbeil and hoisting the flag, the Israeli troops were soon forced to withdraw from the town with heavy casualties. ${ }^{48}$ This abortive operation was a prime example of the ease with which a war psychologically waged and psychological warfare can be confused: the result being a half-baked operation, which badly misfired.

Hezbollah countered the Israeli campaign by often forcefully preventing the local population from fleeing the scene of battle, thus ensuring maximum civilian casualties. And, when there weren't sufficient casualties on the ground, it was quick to inflate numbers, backing its spurious numerical claims by a method nicknamed "faux-tography." In the case of the now infamous Qana affair, it meant exhuming dead bodies from their graves and placing them amidst the rubble of bombed-out buildings, or simply posing as dead for the benefit of Hezbollah photographers' photo-ops. Admittedly, at Qana the deception was soon discovered, but by then the damage had already been done, with, on the one hand, the Israeli government limiting all air-force activity for forty-eight hours, thus giving the Hezbollah a much needed respite, and, on the other, the images of the body-strewn rubble firmly imprinted on most Lebanese minds. ${ }^{49}$

Finally, much psyop value went unused by the IDF neglecting to consider the crucial period after the war when strategic political issues arise, such as who really won the war and the resulting political implications, which Nasrallah was quick to grasp. The IDF failed to conduct interviews with Hezbollah POWs, challenging the organization's heroic stature. It also missed the opportunity to demonize Hezbollah by exposing forced labor (often child labor) and overall use of Lebanese civilians as human shields.

\section{Conclusions}

Its partial successes aside, what is the explanation for the failure of the Israeli psyop campaign? To begin with, it is impossible to separate the Israeli psyop debacle from its less than happy, overall military performance. Psyop does not operate in a vacuum, and just as it can promote military objectives, so military successes on the ground are crucial to the attainment of psyop goals. Even the most well thought-out psyop campaign would flounder in cases where the enemy is able to boast one or more military achievements. Accordingly, the IDF's failure to stop the Hezbollah's rocket barrage defeated any attempt on Israel's part to claim victory, let alone present the war as a total Hezbollah defeat.

Past checks and reversals, too, had an adverse effect on Israel's psyop campaign. The Israeli withdrawal from southern Lebanon, in May 2000, boosted Hezbollah morale, cementing its reputation with many factions in Lebanon. Nor was this the last of the Hezbollah's triumphs. In October 2000, it abducted three Israeli soldiers; like the kidnapping earlier that month of an Israeli businessman, 
Col. (res.) Elhanan Tannenbaum, this exploit passed without any response, other than the prerequisite diplomatic protests. ${ }^{50}$ Both incidents were trumpeted by the Hezbollah as a spectacular military feat. But, in January 2004, the organization went one better, negotiating the release of 429 prisoners and administrative detainees, in return for that of Tannenbaum and the three, dead, soldiers. The exchange, celebrated throughout Lebanon as a huge political coup, raised the Hezbollah's prestige to new and dizzying heights, silencing its detractors while winning it many new supporters.

Then there is Shi'isim's strong seductive force, offering its supporters long-term religious ideological support, which meant that Israel's hopes of driving a wedge within the Hezbollah and/or between Lebanon's various Shi'ite factions had little chance of success. Taken together, all this suggests that, under the circumstances, the Israeli psyop campaign started at a significant disadvantage and that the odds of shattering Nasrallah's and his organization's virtually impregnable social, political, religious, and military standing were very low indeed. Hezbollah's morale received a further boost during the war due to the organization's meticulous monitoring of Israeli media, replete with stories about the mass evacuation of northern Israel and government ministers floundering helplessly about.

In Israel, widespread criticism over the conduct of the war-criticism voiced by army reservists, bereaved parents, the media, and politicians alike - also played a key role in the Israeli psyop campaign's failure. In a military conflict such as this, in which no side is able to claim clear victory, the atmosphere on the home frontthe image projected to the outside world - is crucial to the psyop campaign's success. The outcry in Israel over the way the war was handled, which began during the offensive itself, fell on attentive Lebanese ears, neutralizing many of the MALAT's up-beat messages. Playing into the hands of the Hezbollah, Israeli carping and faultfinding bolstered Nasrallah's attempts to portray Israel as a power in decline, plagued by a feeble and divisive society. ${ }^{51}$

Nor can one ignore the time element as a factor in the Israeli failure. As a rule, psychologically based processes of persuasion take a long time to take root. It requires a concerted effort to modify, let alone overhaul, attitudes and behavior, especially when speaking of strongly ingrained beliefs. Thus, a thirty-three-day campaign starts with a significant handicap. Then there is the fact that the events of July 2006 caught Israel by surprise. Unprepared, it went to war without a well thoughtout, preconceived psyop plan: a plan which, based on a comprehensive, detailed assessment of what psyop can and cannot achieve within the Lebanese context, would have enabled it to set clearly defined, limited and, so, attainable goals. In the event, Israel's psyop campaign appears to have been a hastily cobbled together affair, composed of a series of ad hoc measures. Admittedly, wars can break out by surprise and frequently develop contrary to expectation, which is why it is always advisable to have one or more psyop strategies at hand.

The lack of a pre-prepared plan to deal with the Hezbollah was part of a more general pattern, indicative of Israel's overall inadequate psyop milieu, one whose shortcomings became apparent both during the course of Israel's twenty-year-long battle with the Hezbollah, as well as during the two Palestinian Intifadas (19871991; 2000-2005). As noted, in 2005, bent on improving its dismal psyop record, Israel shut down its old psyop unit, replacing it with an entirely new outfit: the MALAT. The problem was that in ridding itself of the old, Israel, intent on making a new sweep of things, threw out the baby with the bathwater, so that the MALAT 
had to start virtually from scratch with no operational experience to its name. Nor did it have the time to formulate an effective psyop offensive against an opponent like the Hezbollah.

But the reasons for the Israeli failure go beyond any particular set of problems peculiar to the Israeli-Lebanese context. It was also the result of more universal difficulties, both conceptual and structural, of the kind that generally afflict sovereign, democratic states when waging a psyop campaign. First, established states are inclined to rely on their military capabilities to secure victory in the field. As a result, psyop is often located very low in the army priorities list. This bias also held true in Israel, which tended to sideline its psyop unit, allotting it a minimum of facilities. It also meant that during the war the newly reconstructed MALAT found it difficult to tailor and/or co-ordinate its activities with what was happening in the field. Secondly, the MALAT as part of a conventional army was hamstrung by unwieldy administrative processes and, operating in the context of a democracy, was unable to respond quickly, creatively to events: all qualities that are essential to the waging of a successful psyop campaign.

No less important was Israel's failure to christen the 2006 conflict forthwith. True, Israel regarded the events of July-August 2006 not as a war, but as an extended military campaign. However, for psyop purposes each conflict, however small, should be allotted a name and as soon as possible. A well-chosen tag serves to define the nature, aims, indeed the very essence of the conflict, thus putting it into a particular, chosen context. This in turn allows one to garner support for the conflict both within the ranks of the fighting forces, as well as with the public at large, at home and abroad. Naming the conflict, offering an interpretation of the conflict in codified form, might also cause some in the enemy camp to reevaluate their view of events. In March 2007 the Israeli government finally dubbed the conflict "The Second Lebanon War," a somewhat anemic title, which, carrying with it the unhappy memories of the failures of the First Lebanon War, can be considered one more psyop failure. The Hezbollah on the other hand was quick to frame the war as a "Divine Victory" and construct a museum to celebrate its self-declared victory. ${ }^{52}$

All in all, given the massive constraints under which it was forced to operate, the MALAT performed reasonably well. But reasonable is not good enough, and should Israel wish to wage a better, more effective psyop offensive in the future, it must draw on and learn from the mistakes of its 2006 campaign.

First, if the events of July-August 2006 prove anything, it is just how vital coordinating military action and psyop policy actually is. Psyop, by preparing the ground for the conflict before the battle begins, can do much to ease the lot of the fighting forces; it can also support specific military operations. At the same time, it can do little if the war, deliberately or not, develops in ways at odds with its own set goals; it can do even less if it is kept out of the loop and so unable to rethink its strategy and tactics.

Second, a successful psyop campaign does not begin with the outbreak of hostilities nor does it end once the fighting dies down. Gathering information on the enemy, immersing oneself in his culture, mapping out his psychological strong points and weaknesses, are all crucial to the waging of a fruitful psyop campaign and must be tackled well before the conflict gets underway. Nor should the psyop campaign conclude once the last shot is fired. Maintaining a positive, up-beat image abroad while undermining that of the enemy helps underpin one's military and political goals, while, conversely, projecting a negative self-image can unravel all the good 
work done. In sum: a conventional army should learn the potential gains of psyop, incorporate it within its units, deploy it early on, and copy the ways its flexible enemies are using them against him.

\section{Notes}

1. Reserve forces estimate, 3000-5000 strong. INSS Military Balance 2006, at http:// www.inss.org.il/upload/(FILE)1188997948.pdf.

2. See U.S. Army PSYOP Field Manual (1979), available at http://www.fas.org/irp/ doddir/armyp/fm33-1/index.html. Also Doctrine for Joint Psychological Operations, at http://www/iwar.org.uk/psyops/resources/us/jp3-53.pdf, and P. M. A. Lineberger, Psychological Warfare (New York: Arno Press, 1954).

3. "IDF reviving psychological warfare unit," Ha'aretz, 25 January 2005, http:// www.freerepublic.com/focus/fr/1328145/posts.

4. See Milan N. Vego, "Commentary: Effects-Based Operations: A Critique," Joint Force Quarterly, Issue 41, 2nd quarter (2006). http://www.ndu.edu/inss/Press/jfq_pages/ editions/i41/i41_commentary_01.pdf.

5. Mainly the work by Brig. (res.) S. Naveh and team at the IDF Staff College; see also H. Asa and Y. Ya'ari, Lochama Mevuzeret-Milchama Bameah Ha'esrim Ve'achat (Decentralized Warfare-War in the Twenty-first Century) (Tel Aviv: Miskal-Yediot Aharonot, 2005).

6. Ofer Shelah and Yoav Limor, Shvuyim Be'Levanon (Captives in Lebanon) (Tel Aviv: Miskal-Yediot Aharonot, 2007), 178-79.

7. Psyop has played a negligible role in IDF operations. Nevertheless, in almost every war Israel has fought there was some small-scale psyop activity, mostly limited to dropping leaflets from airplanes. Amir Rapoport, Esh Al Kochotenu (Friendly Fire) (Tel Aviv: Ma'ariv, 2007); Amos Harel and Avi Issacharoff, Kurei Akavish (Spider Webs) (Tel Aviv: Miskal-Yediot Aharonot, 2007). Also the Winograd Report, http://www.vaadatwino.org.il/reports.html\#null.

8. See Daniel Lerner, ed., Propaganda in War and Crisis (New York: George W. Stewart, 1951), 267.

9. See literature survey in R. Pape, Bombing to Win Air Power and Coercion in War (Ithaca, NY: Cornell University Press, 1996), chs. 1-3.

10. For differences of campaigns, see S. E. Kreps, "The 2006 Lebanon War: Lessons Learned," Parameters 37 (Spring 2007): 72-84.

11. Shelah and Limor (see note 6 above), 127, 130-31. 203-4.

12. The Winograd Commission Final Report (see note 7 above), 100.

13. Interviews with IDF officers who participated in the ground offensive and helped unearth the Hezbollah's bunker network, September 2006.

14. Winograd Report hints at that point in passing, 261. Also mentioned in a report by IDF Spokesman Unit, referring to organizational changes in the intelligence arm as a result of the war, http://dover.idf.il/IDF/News_Channels/bamahana/07/issue29/2903.htm.

15. In Operation Peace for Galilee, June 1982, the IDF deployed a psyop campaign as well, but it was limited to air-dropped leaflets and radio broadcasts on the Voice of Israel Arabic Service and the "Gray" operation of Radio Voice of the South, which pretended to be Lebanese yet all knew it was supervised by the IDF.

16. Reservations about decapitation were expressed, for example, by Hyder and Pape; see V. D. Hyder, "Decapitation Operations: Criteria for Targeting Enemy Leadership," Army Command and General Staff College, Fort Leavenworth School of Advanced Military Studies; and R. A. Pape, "The True Worth of Air Power," Foreign Affairs 82, no. 2 (March-April 2004): 116-130.

17. Shelah and Limor (see note 6 above), 94 .

18. For an analysis of this dilemma, see FM 33-1-1, Psychological Operations, U.S. Army Headquarters, Washington, 1994, 69.

19. See Raphael Patai, The Arab Mind, rev. ed. (New York: Hatherleigh Press, 2002), 95-99. Also, Daniel Lerner, Psychological Warfare against Germany: The Sykewar Campaign, D-day to VE-day (Cambridge: MIT Press, 1949), 156.

20. See M. Young, "The Hezbollah's Other War," New York Times, 4 August 2006. The relevant Nasrallah clip can be seen on http://www.youtube.com/watch?v=qUClAd3-Z1A. 
21. Major Ran, IDF conference report, 26 December 2006, the Center for Intelligence Studies, in Mabat Malam, no. 48 (March 2007): 5. Also, http://www.intelligence.org.il/ bulletin/bulletin.htm.

22. See http://www.psywar.org/apdsearchform.php?Search=Search\&war=Israel-Lebanon $\% 20 \mathrm{War} \% 202006$ for a selection of Israeli leaflets in Arabic.

23. The Israeli dailies and TV channels were excitedly reporting the raid yet the commentary columns were quick to point out that very little was achieved. The loss of a revered officer of the prestigious Sayeret Matkal unit which performed the raid finalized the gloomy atmosphere.

24. FM 33-1-1 provides a detailed analysis of desired cohesive and divisive behaviors. FM 33-1-1, "Psychological Operations Techniques and Procedures," U.S. Army Headquarters, Washington, 1994, ch. 6.

25. FM 33-1-1, 10-32.

26. See C. Jones, "A Reach Greater than the Grasp: Israeli Intelligence and the Conflict in Southern Lebanon, 1990-2000," Intelligence and National Security 6, no. 3 (September 2001); M. Ranstrop, "The Strategy and Tactics of the Hezbollah's Current Lebanonization Process," Mediterranean Politics 3 (1998): 103-34. See also, M. Conway on the Hezbollah cyberwar: http://www.essex.ac.uk/ecpr/events/jointsessions/paperarchive/edinburgh/ws20/ Conway.pdf.

27. Al Manar produced a clip right after Israel's 2000 withdrawal from Lebanon, showing a stack of army boots piled up in the form of the IDF's logo, an ironic reference to the iconic 1967 image of Egyptian army boots strewn across the Sinai desert.

28. Al Manar broadcasts via satellite 24/7 to the Middle East, Asia, Africa, Europe, and North and South America: http://www.terrorism-info.org.il/malam_multimedia/html/final/ sp/6_04/al_manar.htm\#1. Hezbollah's Radio Nur transmissions were received throughout Israel allegedly via hidden transmitters in Arab villages in the Galilee http://www.ynet. co.il/articles/1,7340,L-2704814,00.html.

29. The caricature and accompanying caption can be seen at http://www.psywar.org/ israellebanon.php.

30. A. R. Norton, "Hezbollah of Lebanon: Extremist Ideas vs. Mundane Politics" (Council on Foreign Relations, NY 1999), at http://www.cfr.org/content/publications/ attachments/Norton2.pdf. Hezbollah has been careful to present the Lebanese national flags with its cedar tree emblems next to its yellow-green flags since the mid-1990s. This was especially conspicuous in the victory celebrations following Israel's retreat in May 2005. Many Hezbollah video clips feature both flags; see for example http://www.youtube.com/watch? $\mathrm{v}=\mathrm{oWeC} \_$VDLyLk\&NR $=1$.

31. God has a central role in Hezbollah's politics (Party of God, Nasrallah [meaning "God's victory"], religious garb, quotes, etc.). This scenery apparently has upset (Christian) Prime Minister Siniora, who made an emotional speech in December 2006. See J. Totten, "Siniora to Nasrallah: You Are Not God," http://www.michaeltotten.com/archives/ 001338.html.

32. Israel deployed a similar message during the Second Intifada, quoting the wife of the Hamas leader in Gaza, who refused to let her son join the Shaheed (Martyr) Brigades: http:// www.opinionjournal.com/best/?id=110002068.

33. For an image of the air-freshener, see http://www.psywar.org/israellebanon.php.

34. See http://beirutlive.blogspot.com in http://www.psywar.org/israellebanon.php.

35. Major Ran, op.cit. See http://www.intelligence.org.il/bulletin/bulletin.htm.

36. See http://www1.idf.il/DOVER/site/mainpage. $a s p ? s l=H E \& i d=7 \&$ docid=56667.HE.

37. "A Mother's Anguish Renewed," at http://www.time.com/time/world/article/ $0,8599,1218760,00 . h t m l$.

38. "Walid Criticizes Nasrallah," in the Lebanese daily A Sharq Al-Awsat, 24 July 2006, at http://72.14.221.104/search?q=cache:0ApVNyPbN0J:fdd.typepad.com/fdd/2006/ $07 /$ index.html.

39. One of Nasrallah's deputies, Mahmoud Komati, helped bolster this message by later admitting that Nasrallah had misjudged the Israeli "overreaction" to the kidnapping. See "Israel to Occupy Area of Lebanon as Security Zone," at http://www.nytimes.com/2006/ 07/26/world/middleeast/26mideast.html.

40. See http://www.4law.co.il/leb1.html. 
41. See http://www.psywar.org/israellebanon.php, which contains several examples of these leaflets.

42. See BBC monitoring: "Israel Steps-up 'Psy-ops' in Lebanon" at http://news. bbc.co.uk/2/hi/middle_east $/ 5217484$. stm.

43. See http://www.4law.co.il/leb1.html.

44. Though survey methodologies are problematic in authoritarian societies, the polls conducted in Lebanon after the war are the "next best" data available. The IDF did not release any information on the Lebanese target audience research (if it indeed had conducted any). Data interpretations should differentiate between surveys during the war when unity feelings are at their height, and postwar surveys which allow the respondents some perspective. According to some partial data collected after the war, ethnic loyalties prevailed. See http:// www.mideastmonitor.org/issues/0609/0609_6.htm.

45. According to Limor, despite strong hints from Nabih Berry that should Israel leave his organization, AMAL, alone, it would remain out of the conflict. Israel attacked AMAL's Beirut headquarters. The result: Berry promptly joined forces with his arch-enemy, Nasrallah. This is another example of the gross lack of coordination between the various branches of the IDF. See Shelah and Limor (note 6 above), 89.

46. See http://www.washingtoninstitute.org/templateC05php?CID $=2500$. Also see an interview with Professor Hilal Khasan, in which Khasan, a member of the American University of Beirut's political science department, made no attempt to hide his identity. See http:// www.time.com/time/magazine/article/0,9171,1226138,000.html.

47. See also the scathing article on the Hezbollah written by Mona Fayyad, a psychology lecturer and herself a Shi'ite: MEMRI Special Dispatch Series, no. 1258. Also the harsh criticisms voiced by the Mufti of Jebel Amil: MEMRI Special Dispatch Series, no. 1266. Both at: http://www.jcpa.org/brief006-11.htm.

48. Rapoport (note 7 above), 265.

49. See http://www.nrg.co.il/online/1/ART1/456/968.html, also see Marvin Kalb, "The Israeli-Hezbollah War of 2006," in Joan Shorenstein Research Paper Series. http:// www.ksg.harvard.edu/presspol/research_publications/papers/research_papers/R29.pdf.

50. Tannenbaum was lured into a meeting in Dubai, where he was drugged and then smuggled into Lebanon.

51. The resignation of General Dan Chalutz in January 2007-well before the publication of the Winograd Commission's interim report - and later the resignation of Defence Minister Peretz, were hailed by the Hezbollah as further proof that it had won the war, allowing Nasrallah to hammer home his vision of a weakened Israel.

52. See Inside "Hizballah Museum," Time (August 15, 2007). http://www.time.com/ time/world/article/0,8599,1653282,00.html?xid=feed-cnn-topics. 